\title{
The incidence and productive significance of ovine toxoplasmosis in Southern Brazil
}

\author{
Incidência e significância econômica da toxoplasmose ovina no sul do Brasil
}

\author{
Fernando Caetano de Oliveira ${ }^{I^{*}}$ Plínio Aguiar de Oliveira $^{\mathrm{I}}$ Nilton Azevedo da Cunha Filho \\ Cintia Lidiane Guidotti Aguiar ${ }^{\mathrm{I}}$ Felipe Geraldo Pappen ${ }^{\text {II }}$ \\ Jeronimo Lopes Ruas ${ }^{I}$ Nara Amélia da Rosa Farias ${ }^{I}$
}

\begin{abstract}
This research aimed to determine incidence of Toxoplama gondii infection in Corriedale sheep in southern Brazil during pregnancy and the extent of associated losses. Blood samples were collected from 411 Corriedale sheep in two flocks at different locations in the state of Rio Grande do Sul (Brazil). Presence of T. gondii was diagnosed by the Indirect Fluorescent Antibody Technique (IFAT). Seroprevalence of T. gondii during pre-mating was $20.2 \%$, with no significant difference between the two flocks studied. Infection by $\boldsymbol{T}$. gondii was influenced by ewes'age $(P \leq 0.05)$. The pre-mating seroprevalence did not influence either returning to estrus or pregnancy rates. Weaning rate was significantly higher in pre-positive dams compared to negative ones $(87.9$ and $74.1 \%$, respectively $-P<0.05)$. The incidence of seroconversion was $16.5 \%(54 / 328)$. In seroconverted ewes, a high rate of return to estrus was observed $(P \leq 0.05)$. The incidence of toxoplasmosis suggests production losses equivalent to $1.87 \%$ per year, in this system production. In addition, toxoplasmosis decreased the number of lambs per ewe. Therefore, to improve livestock performance, $\boldsymbol{T}$. gondii infection should be monitored and controlled in the studied area.
\end{abstract}

Key words: Toxoplasma gondii, ewe, pregnancy, losses.

\section{RESUMO}

Este trabalho tem como objetivo determinar a incidência da infecção pelo T. gondii em ovinos, durante o periodo gestacional e a extensão das perdas associadas. Amostras de sangue foram coletadas de 411 ovelhas Corriedale em dois rebanhos, em diferentes locais do Rio Grande do Sul, Brasil. Presença de T. gondii foi diagnosticada pela técnica de imunofluorescência indireta (RIFI). A soroprevalência no préacasalamento foi de $20,2 \%$, sem diferença significativa entre os dois rebanhos estudados. A infecção por T. gondii foi influenciada pela idade $(P \leq 0,05)$. A soroprevalência no pré-acasalamento não influenciou a taxa de retorno ao estro e a taxa de prenhez. Taxa de desmame foi significativamente maior nas ovelhas positivas na pré-cobertura em comparação com as negativas $(87,9$ e 74,1\%, respectivamente - $P<0,05)$. A incidência de soroconversão foi de 16,5\% (54/328). Em ovelhas que soroconverteram, uma alta taxa de retorno ao estro foi observada $(P \leq 0,05)$. A incidência da toxoplasmose sugere perdas de produção equivalentes a 1,87\% ao ano nestes sistemas. Além disso, a toxoplasmose diminuiu o número de cordeiros por ovelha. Portanto, para melhorar o desempenho produtivo nos rebanhos ovinos, a infecção por $\boldsymbol{T}$. gondii deve ser monitorada e controlada na área estudada.

Palavras-chave: Toxoplasma gondii, ovelhas, gestação, perdas.

\section{INTRODUCTION}

Toxoplasma gondii (Protozoa: Apicomplexa) is a cyst-forming protozoa with worldwide distribution and low parasitic specificity. Sheep is one of the intermediate hosts more susceptible to acute infection (HILL \& DUBEY, 2013), which may lead to abortion and prenatal death (FTHENAKIS etal., 2012).

Hence, toxoplasmosis directly affects sheep flocks, beingthemaincauseoflossesinmanycountries, suchasAustralia (WALDELAND, 1977), New Zealand (CHARLESTON, 1994), Unuguay (FREYRE et al., 1997) and Czech Republic (BÁRTOVÁ et al., 2009). In Brazil, toxoplasmosis prevalence in sheep fluctuates depending on flock management strategies (SOARES et al., 2009). In Greece, ANASTASIA et al. (2013) observed difference in seroprevalence between cattle and sheep under mixed grazing, being higher in sheep, probably due to differences in grazing habits.

Congenital toxoplasmosis is not only a serious public health problem to humans, but it also has a huge economic importance for sheep industry (WANG et al., 2011). Abortion losses caused by $\boldsymbol{T}$. gondii infection in the UK are in the range of 1.2-2.2\% (BUXTON et al., 2007). In Uruguay, FREYRE et al. (1997) estimated losses in sheep industry around 1.4 and 3.9\%, reaching US\$ 4.7 million per year. Furthermore, toxoplasmosis represents a risk to public health, since ingestion of raw or rare ovine meat is an important source of human infection, provoking occasional outbreaks (BONAMETTI et al., 1997).

\footnotetext{
'Departamento de Microbiologia e Parasitologia, Instituto de Biologia, Universidade Federal de Pelotas (UFPEL), s/n, CP 354, 96010-900, Pelotas, RS, Brasil. E-mail: fcoliveiravet@gmail.com. "Corresponding author.

IIInstituto Federal Catarinense, Concórdia, SC, Brasil.
} 
Due to its flourishing sheep industry, it is important to monitor the impact of toxoplasmosis in ovine stock in this region. The present study aimed to determine Toxoplasma infection rate in ewes during pregnancy and to estimate productive losses in ewes of contracting the protozoa infection in extensive farming in Southern Brazil.

\section{MATERIALS AND METHODS}

Experimental animals

Two sheep flocks were studied, containing 131 and 280 Corriedale breed sheep, from farm A ( $31^{\circ} 42^{\prime} 38.14^{\prime \prime} \mathrm{S} 52^{\circ}$ $\left.54^{\prime} 42.23^{\prime} \mathrm{W}\right)$ and farm B (31 $\left.58^{\circ} 44.78^{\prime \prime} \mathrm{S} 53^{\circ} 27^{\prime} 31.55^{\prime \prime} \mathrm{W}\right)$ respectively. Ewes were monitored in the pre-mating period and subsequently when lambs weaned. The period for natural sheep mating was 45 days, with rams of verified fertility. Pregnancy diagnosis was performed by ultrasonography 30 days after mating period, with an estimated time of pregnancy. The adopted farming system is considered extensive and mixed (sheep with cattle) and uses food supplement during critical periods, such as pre-mating and pre-partum.

\section{Blood samples}

Blood was collected from 411 sheep in reproductive age, during pre-mating and post-partum periods, with intervals of seven months between each collection. Both farms showed history of abortion and neonatal mortality. Samples were collected using vacutainer-type tubes without anticoagulant by jugular venipuncture. Collected blood was allowed to stand at room temperature for clot formation, and then cooled down $\left(2^{\circ} \mathrm{C}\right)$. Serum was centrifuged at $2.500 \mathrm{G}$ for 10 minutes and stored at $-20^{\circ} \mathrm{C}$.

\section{Serological examination}

Serum samples were examined for $\boldsymbol{T}$. gondii IgG antibodies using an indirect fluorescence antibody test (IFAT), as described by CAMARGO (1974). An antisheep IgG conjugate antibody (Sigma Chemical ${ }^{\mathbb{R}}$ ) and a commercial antigen obtained from WAMADiagnostic ${ }^{\circledR}(\mathrm{ME}$ 49 strain of $\boldsymbol{T}$. gondii) were used in immunological tests. The cut-off point was 1:64. Positive and negative control sheep sera were always included in antibody detection assays.

\section{Statistical analyses}

Seroprevalencerates were defined according to the percentage of samples tested with antibodies against $\boldsymbol{T}$. gondii. Incidence was calculated considering seronegative animals under risk of acquiring infection (ORTEGA-PACHECO et al., 2011), along with those becoming seropositive throughout the experimental period. Significance production loss was estimated essentially as described by FREYRE et al. (1997), by the formula: A - B x 4/7 x 0.25, where A: post-partum seroprevalence, B: pre-mating seroprevalence, 4 is the period (in months) where susceptible ewes may suffer abortion due to toxoplasmosis, 7 is the time elapsed (in months) between the first and second seroprevalence analysis and 0.25 is the abortion rate (considering a natural infection scenario, in agreement with WALDELAND, 1977).

$P$ values were obtained with the chi-square test (for low frequencies) or the Fisher's exact test, employing the Statistix ${ }^{\circledR}$ 9.0 software package(Analytical Software, Tallahasee, FL, USA).

\section{RESULTS AND DISCUSSION}

The overall seroprevalence during the premating period was $20.2 \%(83 / 411)$. It was significantly influenced by increase of age $(P<0.01)$. The increase in prevalence depending on ewes' age observed in Rio Grande do Sul suggests the occurrence of horizontal infection by oocysts, as likewise pointed out by BUXTON et al. (2007) in Scotland. In Paraná State (Brazil), OGAWA et al. (2003) reported that the percentage of ewes seropositive to T. gondii is greater when they are older than two years.

Therefore, $79.8 \%$ (328/411) of reproductive dams did not show antibodies against $\boldsymbol{T}$. gondii, and were susceptible to protozoal infection. No difference was observed between seroprevalence of flocks A and B, including age groups of ewes, both for pre-mating, and post-partum ewes. Therefore, subsequent analysis of data was performed considering both flocks as a single unit.

Flock seroprevalence in post-partum period was significantly higher than in the pre-mating period $(P<0.05)$ (Table 1). Post-partum seroprevalence was 33.3\% (137/411). Incidence rate was $16.5 \%$ (54/328). Statistical difference between the pre-mating and post-partum seroprevalence is due to the high number of animals that seroconverted during the experimental period. In Uruguay, a similar study conducted by SAVIO \& NIETO (1995), reported that only $10.8 \%$ of dams were seroconverted during the reproductive period, with only $34.2 \%$ weaned lambs.

In the present research, seroconversion rate was higher, but it did not affect the weaning rate. Such a difference may be ascribed to virulence variations between Toxoplasma strains (DUBREMETZ \& LEBRUN, 2012). Group of dams that seroconverted during pregnancy had higher rates of estrus return $(P<0.05)$, but had no significant differences were reported between pregnancy and weaning rates (Table 2$)$.

Toxoplasmosis is known to cause resorption, abortions and neonatal deaths in lambs (BUXTON, 2007). Such cases were observed among the studied animals

Table 1 - Seroprevalence (RIFI) for $\boldsymbol{T}$. gondii in sheep (dams) in extensive farming, related to reproductive cycle period.

\begin{tabular}{lllr}
\hline Period & Reactive serum \% & Non reactive \% & ----------Univariate analysis--------- \\
& & & $X^{2}$ \\
\hline Pre-mating & $20.2 \%(83 / 411)$ & $79.8 \%(328 / 411)$ & 200 \\
Post-partum & $33.3 \%(137 / 411)$ & $66.7 \%(274 / 411)$ & 0.0001 \\
\hline
\end{tabular}

${ }^{*} P<0.05$ by the chi-square test. 
Table 2 - Association between seroconversion occurrence to $\boldsymbol{T}$. gondii in sheep (dams) during pregnancy, and their productive parameters.

\begin{tabular}{|c|c|c|c|c|}
\hline \multirow{2}{*}{ Productive parameter } & \multirow{2}{*}{ Seroconversion } & \multirow{2}{*}{$\%$} & \multicolumn{2}{|c|}{------------Univariate analysis------.. } \\
\hline & & & OR $(95 \%)$ & $P^{*}$ \\
\hline \multirow{2}{*}{ Estrus return } & Non-converted & $29.4 \%(105 / 357)$ & 1 & \\
\hline & Converted & $44.4 \%(24 / 54)$ & $1,92(1.07-3,43)$ & 0.02 \\
\hline \multirow{2}{*}{ Pregnancy rate } & Non-converted & $95.0 \%(339 / 357)$ & 1 & \\
\hline & Converted & $88.9 \%(48 / 54)$ & $2.35(0,89-6,22)$ & 0.07 \\
\hline \multirow{2}{*}{ Weaning rate } & Non-converted & $76.2 \%(272 / 357)$ & 1 & \\
\hline & Converted & $81.5 \%(44 / 54)$ & $0.72(0.35-1.50)$ & 0.39 \\
\hline
\end{tabular}

OR value $(\mathrm{CI}=95 \%)$ by two-by-two analysis.

${ }^{*} P<0.05$ by the chi-square test.

and were assumed to be due to toxoplasmosis. However, confirmation of this diagnosis was not possible due to extensive farming practices. In UK, a questionnaire-based epidemiological study reported that $72.0 \%$ of sampled ovine livestock farms suffered abortion problems caused by $\boldsymbol{T}$. gondii (LONGBOTTOM et al., 2013).

Seropositive animals in the pre-mating period, (which were theoretically protected from $\boldsymbol{T}$. gondii infection), had lower rate of estrus return and increased pregnancy rates, but such differences were not statistically significant. Weaning rate was significantly higher in this group $(P<0.05)$; moreover, seropositive ewes were 2.55 times more likely to wean lambs $(\mathrm{OR}=2.55$, Table 3$)$.

Data obtained in the present research indicated that toxoplasmosis reduced productive significance by $1.87 \%$. Expanding these results to the state of Rio Grande do Sul, taking into account the sheep production, it is possible to estimate a loss around 35 thousand lambs or US\$ 1.491 million annually, caused by $\boldsymbol{T}$. gondii.

According to BLEWETT \& TREES (1987), incidence of toxoplasmosis is difficult to define, however they concluded that in UK, there is around 1 to $2 \%$ neonatal losses in sheep per year. If such figure is accurate, it can be assumed that about 1.25 million lambs perished due to Toxoplasma infection in the European Union in 2003
(BUXTON et al., 2007). In the UK, DUNCANSON et al. (2001) reported losses of $11.6 \%$ of pregnancies and 9\% of lambs, suggesting that losses occurred in several ways: animals that did not get pregnant, ewes that were unable to complete pregnancy and animals born with severe health problems which did not survive.

Sheep flock in the state of Rio Grande do Sul is 4 million (IBGE, 2012), of which 2.4 million corresponds to dams breeding in the region (SEAPA, 2012). Twenty percent of those were probably immunized against toxoplasmosis by natural infection (PAPPEN, 2008), so that there were yet 1.9 million sheep susceptible to $\boldsymbol{T}$. gondii. According to the present study, this would cause a deficit of more than thirty-five thousand lambs per year. With an average selling price of weaned lamb at state fairs of US\$ 42.00 each (RODRIGUES, 2013), this implies an annual loss of about $\$ 1.491$ million.

\section{CONCLUSION}

Toxoplasmosis infected ewes during pregnancy in two flocks of Southern Brazil, adding a substantial risk to lamb production in this region, with important financial consequences for ovine production in this country.

Table 3 - Association between serological status for $T$. gondii of dams pre-mating period and productive variables of flock in extensive farming.

\begin{tabular}{|c|c|c|c|c|}
\hline \multirow{2}{*}{ Variables } & \multirow{2}{*}{ Serostatus } & \multirow{2}{*}{$\%$} & ----Univariate an & \multirow{2}{*}{$P^{*}$} \\
\hline & & & OR $(95 \%)$ & \\
\hline \multirow{2}{*}{ Estrus return } & Reactive & $24 \%(20 / 83)$ & 1 & \\
\hline & Non-reactive & $33.2 \%(109 / 328)$ & $1.56(0.90-2.72)$ & 0.10 \\
\hline \multirow{2}{*}{ Pregnancy rate } & Reactive & $96.4 \%(80 / 83)$ & 1 & \\
\hline & Non-reactive & $93.6 \%(307 / 328)$ & $1.82(0.53-6.28)$ & 0.33 \\
\hline \multirow{2}{*}{ Weaning rate } & Reactive & $88.0 \%(73 / 83)$ & 1 & \\
\hline & Non-reactive & $74.1 \%(243 / 328)$ & $2.55(1.26-5.17)$ & 0.007 \\
\hline
\end{tabular}

OR value $(\mathrm{CI}=95 \%)$ by two-by-two analysis.

${ }^{*} P<0.05$ by the chi-square test. 


\begin{tabular}{llll}
\hline BIOETHICS & AND & BIOSSECURITY & gov/pubmed/9477487>. Accessed: Feb. 25, 2014. doi: 10.1016/ \\
COMMITTEE & APPROVAL & & S0304-4017(97)00069-1.
\end{tabular}

This research was conducted with the approval of the Ethics Committee on Animal Experimentation at the Universidade Federal de Pelotas, as granted by Opinion No. 2301/2013.

\section{CONFLICT OF INTEREST STATEMENT}

The authors declared no potential conflicts of interest with respect to the research, authorship, and/or publication of this article.

\section{REFERENCES}

ANASTASIA, D. et al. Toxoplasma gondii and Neospora caninum seroprevalencein dairy sheep and goats mixed stock farming. Veterinary Parasitology, v.198, p.387-390, 2013. Available from: <http:// www.sciencedirect.com/science/article/pii/S0304401713005116\#>. Accessed: Feb. 25, 2015. doi:10.1016/j.vetpar.2013.09.017.

BÁRTOVÁ, E. et al. Toxoplasma gondii and Neospora caninum antibodies in sheep in the Czech Republic. Veterinary Parasitology, v.161, p.131-132, 2009. Available from: <http:// www.sciencedirect.com/science/article/pii/S0304401709000211>. Accessed: Feb. 02, 2015. doi:10.1016/j.vetpar.2008.12.022.

BLEWETT, D.A.; TREES, A.J. The epidemiology of ovine toxoplasmosis with special respect to control. British Veterinary Journal, v.143, p.128-135, 1987. Available from: <http://www. sciencedirect.com/science/article/pii/0007193587900042>. Accessed: Dec. 10, 2014. doi:10.1016/0007-1935(87)90004-2.

BONAMETTI, A.M. et al. Surto de toxoplasmose aguda transmitida através da ingestão de carne crua de gado ovino. Revista Sociedade Brasileira de Medicina Tropical, v.30, p.21-25, 1997. Available from: <http://www.scielo.br/pdf/rsbmt/v30n1/0655.pdf >. Accessed: Mar. 25, 2015. doi: 10.1590/S0037-86821997000100005.

BUXTON, D. et al. Toxoplasma gondii and ovine toxoplasmosis: new aspects of an old story. Veterinary Parasitology, v.149, p.25-28, 2007. Available from: $<$ http://www.sciencedirect.com/science/article/pii/S0304401707003524>. Accessed:Apr. 10, 2014. doi:10.1016/j.vetpar.2007.07.003.

CAMARGO, M.E. Introdução às técnicas de imunofluorescência. Revista Brasileira de Patologia Clínica, v.10, p.143-169, 1974. Available from: $<$ https://scholar.google.com/scholar lookup?title=Introdu $\% \mathrm{C} 3 \% \mathrm{~A} 7 \% \mathrm{C} 3 \%$ $\mathrm{A} 3 \mathrm{o}+\mathrm{as}+\mathrm{t} \% \mathrm{C} 3 \% \mathrm{~A} 9$ cnicas + de + imunofluoresc $\% \mathrm{C} 3 \% \mathrm{AAncia} \&$ author $=\mathrm{CA}$ MARGO+M.E.\&publication year $=1974 \&$ journal $=\mathrm{Rev}+\mathrm{Bras}+\mathrm{Patol}+\mathrm{Cl} \% \mathrm{C}$ $3 \%$ ADn\&volume $=10 \&$ issue $=3$ \&pages $=87-107>$. Accessed: Feb. 12, 2015.

CHARLESTON, W.A.G. Toxoplasma and other protozoan infections of economic importance in New Zealand. New Zealand Journal Zoology, v.211, p.67-81, 1994. Available from: <http:// www.tandfonline.com/doi/pdf/10.1080/03014223.1994.9517977. Accessed: Feb. 26, 2015. doi: 10.1080/03014223.1994.9517977.

DUBREMETZ, J.F.; LEBRUN, M. Virulence factors of Toxoplasma gondii. Microbes Infection, v.14, p.1403-1410, 2012. Available from: $<$ http://www.sciencedirect.com/science/article/pii/S1286457912002225>. Accessed: Feb. 10, 2015. doi:10.1016/j.micinf.2012.09.005.

DUNCANSON, P. et al. High levels of congenital transmission of Toxoplasma gondii in a commercial sheep flock. International Journal Parasitology, v.31, p.1699-1703, 2001. Available from: <http://www. sciencedirect.com/science/article/pii/S002075190100282X $>$. Accessed: Mar. 10, 2015. doi:10.1016/S0020-7519(01)00282-X.

FREYRE, A. et al. The incidence and economic significance of ovine toxoplasmosis in Uruguay. Veterinary Parasitology, v.73, p.13-15, 1997. Available from: <http://www.ncbi.nlm.nih.
FTHENAKIS, G.C. et al. Health management of ewes during pregnancy. Animal Reproduction Science, v.130, p.198-212, 2012. Available from: $<$ http://www.sciencedirect.com/science/article/pii/S0378432012000425>. Accessed: Feb. 14, 2015. doi: 10.1016/j.anireprosci.2012.01.016.

HILL, D.E.; DUBEY, J.P. Toxoplasma gondii prevalence in farm animals in the United States. International Journal Parasitology, v.43, p.107-113, 2013. Available from: <http://www.sciencedirect. com/science/article/pii/S0020751912003001>. Accessed: Feb. 25, 2015. doi: 10.1016/j.ijpara.2012.09.012.

IBGE, Banco de Dados Agregados. 2012. Available from: <http:// www.ibge.gov.br/ESTADOSAST/TEMAS.PHP?SIGLA=rs\&tema $=\mathrm{p}$ ecuaria2006\&titulo $=$ Pecu\%E1ria\%202011>. Accessed: Jan. 4, 2015.

LONGBOTTOM, D. et al. Evaluation of the impact and control of enzootic abortion of ewes. Veterinary Journal, v.195,p.257-259,2013. Availablefrom: $<$ http://www.sciencedirect.com/science/article/pii/S109002331200250X>. Accessed: Feb. 25, 2015. doi: 10.1016/j.jppara.2012.09.012.

OGAWA, L. et al. Ocorrência de anticorpos anti-Toxoplasma gondii em ovinos da região de Londrina no Estado do Paraná. Semina Agrárias, v.24, p.57-62, 2003. Available from: <http://www. uel.br/revistas/uel/index.php/semagrarias/article/view/2116>. Accessed: Jan. 4, 2015. doi: 10.5433/1679-0359.2003v24n1p57.

ORTEGA-PACHECO, A. et al. Infection dynamic of Toxoplasma gondii in two fattening pig farms exposed to high and low cat density in an endemic region. Veterinary Parasitology, v.175, p.367-371, 2011. Available from: $<$ http://www.sciencedirect.com/science/article/pii/S0304401710005650>. Accessed: Jan. 4, 2015. doi: 10.1016/j.vetpar.2010.10.018.

PAPPEN, F.G. Prevalence of antibodies against Toxoplasma gondii (Nicolle e Manceaux, 1909) in sheep from the South of Rio Grande do Sul State, Brazil. 2008. 59f. Master Thesis (Master in Veterinary) - Postgraduate Program in Veterinary Medicine, Federal University of Pelotas, RS.

RODRIGUES, R.M.C. $\mathbf{2 6}^{\circ}$ cotação mensal do preço do cordeiro: $\mathrm{kg} /$ carcaça e arroba - outubro de 2013. 2013. Available from: $<$ http://www.farmpoint.com.br/cadeia-produtiva/cotacao-docordeiro/26-cotacao-mensal-do-preco-do-cordeiro-kgcarcaca-earroba-outubro-de-2013-86152n.aspx>. Accessed: Feb. 25, 2014.

SAVIO, E.; NIETO, A. Ovine toxoplasmosis: seroconversion during pregnancy and lamb birth rate in Uruguayan sheep flocks. Veterinary Parasitology, v.60, p.241-247, 1995. Available from: <http:// www.sciencedirect.com/science/article/pii/0304401794007648>. Accessed: Jan. 4, 2015. doi:10.1016/0304-4017(94)00764-8.

SEAPA-RS (SECRETÁRIA AGRICULTURA PECUÁRIA E AGRONEGÓCIO). 2012. Available from: $<$ http://www.agricultura.rs.gov. br/conteudo/1033/?Mais_Ovinos_no_Campo $>$. Accessed: Jan. 20, 2014.

SOARES, H.S. et al. Prevalence of anti-Toxoplasma gondii and antiNeospora caninum antibodies in sheep from Mossoró, Rio Grande do Norte, Brazil. Veterinary Parasitology, v.160, p.211-214, 2009. Available from: $<$ http://www.sciencedirect.com/science/article/pii/S0304401708006389>. Accessed: Jan. 4, 2015. doi: 10.1016/j.vetpar.2008.10.102.

WALDELAND, H. Toxoplasmosis in sheep. I. Long-term epidemiological studies in four breeding flocks. II. Influence of various factors on the antibody contents. III. Hematological, serological and parasitological studies. Acta Veterinary Scandinavian, v.18, p.227-256, 1977.

WANG, T. et al. Toxoplasma gondii: the effects of infection at different stages of pregnancy on the offspring of mice. Experimental Parasitology, v.127, p.107-112, 2011. Available from: <http:// www.sciencedirect.com/science/article/pii/S001448941000247X>. Accessed: Jan. 4, 2015. doi: 10.1016/j.exppara.2010.07.003. 